\title{
MORPHO-PHYSIOLOGICAL RESPONSE OF STEVIA (STEVIA REBAUDIANA BERTONI) TO SALINITY UNDER HYDROPONIC CULTURE CONDITION (A CASE STUDY IN IRAN)
}

\author{
AGHighi SHAVERDI, M. - OMIDI, H. ${ }^{*}$ - TABATABAEI, S. \\ Agronomy and Plant Breeding Department, Agriculture Faculty, Shahed University \\ Tehran, Iran \\ *Corresponding author \\ e-mail: heshmatomidi@yahoo.com,omidi@shahed.ac.ir \\ (Received $17^{\text {th }}$ Jun 2017; accepted $18^{\text {th }}$ Oct 2017)
}

\begin{abstract}
Stevia (Stevia rebaudiana Bertoni) is a relatively unknown crop in Iran and many countries of world, with great potential as a natural sweeteners source. Stevia has a high content of sweeteners, which are up to 150 times sweeter than sugar, but virtually with no calories. An experiment was carried out to investigate the effect of salinity stress on root characteristics and physiological traits of stevia using six different concentrations of $\mathrm{NaCl}(0,30,60,90,120$, and $150 \mathrm{mM})$ in Hoagland solution with four replications in open shading structures at Medicinal Plant Research Center, Shahed University of Tehran, Iran. The results showed that root characteristics (such as root fresh weight (RFW), root dry weight (RDW), root volume (RV), root length (RL), root area (RA), root diameter, root mass density (RMD), and dry root mass density (DRMD)) reduced with the intensification of $\mathrm{NaCl}$. The effect of $\mathrm{NaCl}$ was significant on the protein content, activity of catalase (CAT), peroxidase (POD), polyphenol oxidase (PPO), and DPPH. The increasing of $\mathrm{NaCl}$ caused significantly enhancement of protein content, CAT activity, and total antioxidant activity. The POD activity showed a significant decrease by the increasing of sodium chloride rate. The PPO and POD activities by the increasing sodium chloride rate showed a significant decrease. Steviol glycosides (SVglys) compositions: stevioside (Stev), rebaudioside A (Reb A), rebaudioside B (Reb B), rebaudioside C (Reb C) and dulcoside A (Dulc A) and SVglys content showed changes under the influence of salinity. In $30 \mathrm{mM} \mathrm{NaCl}$ treatment was obtained the highest value of total SVglys yield and SVglys content. The findings from this study lead to the conclusion that, salinity stress caused reduces root characteristics and changes in physiological traits (protein content, activity of CAT, POD, PPO and total antioxidant activity DPPH). On the other hand, at the lowest salinity level $(30 \mathrm{mM})$, the highest amount SVglys was obtained. It seems that the high level of SVglys at lower salinity levels is one of the reasons for salinity tolerance in Stevia, which requires further investigation.

Keywords: enzyme activity, Hoagland, $\mathrm{NaCl}$, peroxidase, root, steviol glycosides
\end{abstract}

\section{Introduction}

The herb of stevia (Stevia rebaudiana Bertoni) also known as a honey leaf is a perennial plant and from the Asteraceae (Compositae) family native to Brazil and Paraguay (often referred to as the herb of Paraguay) (Karimi et al., 2015). The plant has a sweet taste due to the presence of diterpene SV glys. Stev and Reb-A are dominant glycoside compositions of the plant which makes that plant to be even 300 times sweeter than sucrose (Hajihashemi and Ehsanpour, 2014). This plant is of worldwide importance and high demand in many countries (such as Japan, Korea, China and South America) which are high potency natural sweeteners and low-calorie (Barbet-Massin et al., 2016).

The plant can, apparently, be successfully grown under different conditions regarding climate and soils (Hajar et al., 2014). The plant is adapted to poor soils, with low nutrient requirements. However, stevia shows some variability in what concerns the sensitivity or tolerance to salinity stress (Reis et al., 2015). There is often a tendency for 
a relation between growth and yield of crops, and salinity that is well established in the scientific literature: usually, the higher salinity levels the less growth and yield of the crop (Ityel et al., 2012; Jamil et al., 2012; Reis et al., 2015).

Salinity is one of the most hazardous and limiting environmental factors of crop product and plant growth particularly in arid and semi-arid regions (Gharsallah et al., 2016). FAO (2015) reported that 800 million ha of land and 32 million ha of agricultural land are estimated salt affected. The soil salinity of decreased water uptake by the root plants and causes osmotic stress, ion toxicity and mineral deficiencies (Munns and Tester, 2008).

Responses of plants to salinity stress (including physiological and morphological modifications) depending on the stage of growth and the genotype (Montana et al., 2014). Different types of salts exist in agricultural lands (such as $\mathrm{Na}_{2} \mathrm{SO}_{4}, \mathrm{Na}_{2} \mathrm{CO}_{3}, \mathrm{KCl}$, $\mathrm{CaSO}_{4}, \mathrm{MgSO}_{4}, \mathrm{MgCl}_{2}$ and etc) each of which can lead to the salinity stress (Bazrafshan and Ehsanzadeh, 2016). However, in salinity stress are dominant mostly $\mathrm{Na}^{+}$and $\mathrm{Cl}^{-}$concentrations (Montana et al., 2014), thus $\mathrm{NaCl}$ is commonly the most widespread and disadvantageous salt in agricultural lands of Iran and other countries (Azizpour et al., 2010).

Salinity stress has been reported (Wu et al., 2010) to cause reactive oxygen species (ROS) formation and accumulation in the plant. Oxidative stress defenses happen through an enzymatic antioxidant mechanism including CAT, SOD, POD and nonenzymatic antioxidants as phenolics, flavonoids (Gharsallah et al., 2016).

Plant roots are the first organ to experience the effects of salt stress and essential to plant maintenance, as well as, have an important function in determining the yield of crops (Ober and Sharp, 2007). The widespread root system is positively correlated with salinity tolerance. Variations in the number of roots, root length, and its growth rate have been observed in different varieties and plants that these traits may create differences in plant characteristics such as tolerance to drought and salinity stresses (De-Oliveira and Varshney, 2011). The root of the plant's longer and more lateral roots than fewer plants that this attribute is more tolerant to salinity stress. An important factor in the tolerance to salinity how to develop their root system (Singh et al., 2000). Increased root surface is important since caused increased levels of absorption and increasing the efficiency of water and nutrients. Therefore, longer roots and more root surface can be provided possibility salinity tolerance (Aghaei et al., 2009).

The cultivation of stevia multipurpose plant caused increasing its production for medicinal and other purposes. There is much research on potential uses, micropropagation, and cell culture, secondary metabolite production of this plant. However, there are only a few reports available on biochemical modifications and without reported on root characteristics of stevia in $\mathrm{NaCl}$ salinity condition (Gupta et al., 2016). On the other hand, root characteristics and biochemical traits modifications are important for understanding salinity tolerance mechanism, but strategies differ among plant species (Liu et al., 2016). Therefore, there is a need to research on modifications of root parameters and biochemical traits of the plant. So, in the present research was planned with objectives the assess of six different concentrations of $\mathrm{NaCl}$ $(0,30,60,90,120$, and $150 \mathrm{mM})$ on root characteristics and physiological traits of stevia. 


\section{Material and methods}

\section{Plant material and growth conditions}

The present study was carried out based on a completely randomized design (CRD) with four replications in open shading structures at Medicinal Plant Research Center, Shahed University of Tehran, Iran. The seedling of stevia (Stevia rebaudiana Bertoni) propagation was carried out by tissue culture. The uniform two seedlings were transplanted into the pot $(30 \times 30 \mathrm{~cm})$ containing a mixture of pumice and perlite $(50: 50$ ratio). Two weeks after establishment of seedlings were subjected to salinity stress with different $\mathrm{NaCl}$ (Sodium chloride; Merck, Darmstadt, Germany) concentration (0, 30, 60, 90,120 , and $150 \mathrm{mM}$ ). Salinity treatment was applied according to the treatments 15 days after planting and continued until the end of the experiment. The pots were watered one time a day by mineral nutrients with $500 \mathrm{~mL}$ per pot of modified Hoagland solution (Table 1). The EC and $\mathrm{pH}$ of drainage water from pots were checked every week, and an additional $500 \mathrm{~mL}$ of distilled water was applied to minimize $\mathrm{pH}$ and EC changes in the root zone (Rahimi and Biglarifard, 2011). The whole plants were harvested at 62 days after transplanting and leaves and stems were separated and placed in the freezer $\left(-30^{\circ} \mathrm{C}\right)$ used for further assays.

Table 1. Nutritional composition of used in the preparation of Hoagland solution

\begin{tabular}{|c|c|c|c|}
\hline Macronutrients & Chemical components & Stock solution & ml of stock solution/1 ml \\
\hline $\mathrm{KNO}_{3}$ & $2 \mathrm{M} \mathrm{KNO}_{3}$ & $202 \mathrm{~g} / \mathrm{L}$ & 2.5 \\
$\mathrm{H}_{2} \mathrm{PO}_{4}$ & $1 \mathrm{M} \mathrm{KH} \mathrm{PO}_{4}(\mathrm{pH}$ to 6.0$)$ & $136 \mathrm{~g} / \mathrm{L}$ & 0.5 \\
$\mathrm{Ca}\left(\mathrm{NO}_{3}\right)_{2}$ & $1 \mathrm{M} \mathrm{Ca}\left(\mathrm{NO}_{3}\right)_{2} \cdot 4 \mathrm{H}_{2} \mathrm{O}$ & $236 \mathrm{~g} / 0.5 \mathrm{~L}$ & 2.5 \\
$\mathrm{NH}_{4} \mathrm{NO}_{3}$ & $1 \mathrm{M} \mathrm{NH}_{4} \mathrm{NO}_{3}$ & $80 \mathrm{~g} / \mathrm{L}$ & 1 \\
\hline Micronutrients & & & 1.5 \\
\hline Iron & Iron $($ Sprint 138 iron chelate $)$ & $15 \mathrm{~g} / \mathrm{L}$ & 1 \\
$\mathrm{MgSO}_{4}$ & $2 \mathrm{M} \mathrm{MgSO}_{4} \cdot 7 \mathrm{H}_{2} \mathrm{O}$ & $493 \mathrm{~g} / \mathrm{L}$ & 1 \\
$\mathrm{H}_{3} \mathrm{BO}_{3}$ & $\mathrm{H}_{3} \mathrm{BO}_{3}$ & $2.86 \mathrm{~g} / \mathrm{L}$ & 1 \\
$\mathrm{MnCl}_{2}$ & $\mathrm{MnCl}_{2} \cdot 4 \mathrm{H}_{2} \mathrm{O}$ & $1.81 \mathrm{~g} / \mathrm{L}$ & 1 \\
$\mathrm{ZnSO}_{4}$ & $\mathrm{ZnSO}_{4} \cdot 7 \mathrm{H}_{2} \mathrm{O}$ & $0.22 \mathrm{~g} / \mathrm{L}$ & 1 \\
$\mathrm{CuSO}_{4}$ & $\mathrm{CuSO}_{4} \cdot 5 \mathrm{H}_{2} \mathrm{O}$ & $0.051 \mathrm{~g} / \mathrm{L}$ & 1 \\
$\mathrm{Na}_{2} \mathrm{MoO}_{4}$ & $\mathrm{Na}_{2} \mathrm{MoO}_{4} \cdot 2 \mathrm{H}_{2} \mathrm{O}$ & $0.12 \mathrm{~g} / \mathrm{L}$ & \\
\hline
\end{tabular}

\section{Root parameters calculation}

Underground organ, total roots were washed thoroughly and minimized damages with running water. Root fresh weight was measured immediately with $0.001 \mathrm{~g}$ accuracy. $\mathrm{RV}$ was obtained by subtraction of root volume after inserting it in the certain volume of water to first RV with $0.1 \mathrm{~mm}$ accuracy. RA was evaluated by Atkinson method (Hajabbasi, 2001). Root diameter and volume was obtained by Table 2 relations and other traits such as root fresh weight to soil volume (RMD), root dry weight to soil volume (DRMD), root dry weight to root volume, and root length to root fresh weight (RF) was calculated (Ganjali et al., 2003). 
Table 2. Method of calculation parameters associated with root

\begin{tabular}{|c|c|c|}
\hline Parameters & Formula & Reference \\
\hline Root length (RL) & $\mathrm{RL}=($ roots weight $) \times 0.890$ & Ganjali et al., 2003 \\
Root area (RA) & $\mathrm{RA}=2(\text { Root volume } \times \pi \times \mathrm{RL})^{0.5}$ & Hajabbasi, 2001 \\
Root diameter (RD) & $\mathrm{RD}=(4 \times \text { Root fresh weight } /(\mathrm{RL} \times \pi))^{0.5}$ & Akhavan et al., 2012 \\
Root Surface Area Density RSD $)$ & $\mathrm{RSD}=(\mathrm{RL} \times \mathrm{RD} \times \pi)$ & Akhavan et al., 2012 \\
\hline
\end{tabular}

$\pi=$ constant number 3.14

\section{Protein and antioxidant enzymes assay}

Samples were frozen in liquid nitrogen and stored at $-30{ }^{\circ} \mathrm{C}$. One $\mathrm{g}$ of frozen leaf was homogenized in a mortar with $5 \mathrm{~mL}$ of $50 \mathrm{mM}$ potassium phosphate buffer $(\mathrm{pH}=7.5)$ containing $1 \mathrm{mM}$ ethylenediaminete-traacetic acid (EDTA), $1 \mathrm{mM}$ dithiotreitol and 2\% polyvinyl pyrrolidon (PVP). The homogenate was centrifuged at 15,000 g for $25 \mathrm{~min}$ and the supernatant was used for protein and antioxidant enzyme assay.

\section{Protein content}

For determining the amount (concentration) of protein, spectrophotometer with Bradford method (1976) was used. The basis of this method is binding the Coomassie Brilliant blue G-250 to protein in an acidic environment and determine maximum absorption from 595 to $465 \mathrm{~nm}$. The absorbance at $595 \mathrm{~nm}$ had a direct comparison to protein concentration.

\section{Catalase assay}

The CAT activity assay was performed using Chance and Maehly (1995) method. Three $\mathrm{mL}$ reaction mixture containing $2.5 \mathrm{~mL} 0.05 \mathrm{mM}$ sodium phosphate buffer $(\mathrm{pH}=7), 30 \mu \mathrm{g}$ protein solution was added to quettes and at the time of measurement, $30 \mu \mathrm{L} \mathrm{H}_{2} \mathrm{O}_{2}(30 \%)$ was added to reaction mixture and the absorbance at $240 \mathrm{~nm}$, at $60 \mathrm{~s}$, and at $25^{\circ} \mathrm{C}$ was recorded.

\section{Peroxidase assay}

POD activity was assayed adopting the method of Polle et al. (1994). According to this method, POD activity was determined at $436 \mathrm{~nm}$ by its ability to convert guaiacol to tetraguaiacol $\left(€=26.6 \mathrm{mM}^{-1} \mathrm{~cm}^{-1}\right)$. The reaction mixture contained $100 \mathrm{mM}$ potassium phosphate buffer ( $\mathrm{pH}=7.0), 20.1 \mathrm{mM}$ guaiacol, $10 \mathrm{mM} \mathrm{H}_{2} \mathrm{O}_{2}$ and enzyme extract. The increase in absorbance was recorded by the addition of $\mathrm{H}_{2} \mathrm{O}_{2}$ at $436 \mathrm{~nm}$ for 3 min.

\section{Polyphenol oxidase assay}

The polyphenol oxidase (PPO; E.C. 1.10.3.1) activity was measured according to the method of Raymond et al. (1993) in absorbance at $430 \mathrm{~nm}$. The reaction mixture contained $1900 \mu 150 \mathrm{mM}$ sodium phosphate buffer $(\mathrm{pH}=6.8), 500 \mu$ pyrogallol 0.02 $\mathrm{mM}$ and $100 \mu \mathrm{l}$ enzyme extract. 


\section{DPPH activity}

The measurement of the DPPH radical scavenging activity was performed according to the methodology described by Brand-Williams et al. (1995). The reaction mixture consisted of adding $0.5 \mathrm{~mL}$ of sample, $3 \mathrm{~mL}$ of absolute ethanol and $0.3 \mathrm{~mL}$ of DPPH radical solution $0.5 \mathrm{mM}$ in ethanol. The changes in color (from deep violet to light yellow) were read at $517 \mathrm{~nm}$ after $100 \mathrm{~min}$ of reaction. The mixture of ethanol $(3.3 \mathrm{~mL})$ and sample $(0.5 \mathrm{~mL})$ serve as a blank. The control solution was prepared by mixing ethanol $(3.5 \mathrm{~mL})$ and DPPH radical solution $(0.3 \mathrm{~mL})$.

\section{Determination of SVglys content and compositions}

The SVglys content and compositions of stevia leaves were determined according to the procedures used by other researchers (Ceunen and Geuns, 2013; Karimi et al., 2015). $0.1 \mathrm{~g}$ of powdered leaves (dried at $65^{\circ} \mathrm{C}$ for $48 \mathrm{~h}$ in hot air avon) was transferred to $15 \mathrm{~mL}$ tubes, $3 \mathrm{~mL}$ distilled water were added and kept in a water bath for $30 \mathrm{~min}$ at $80{ }^{\circ} \mathrm{C}$. The resultant solution was firstly centrifuged at $12,000 \times \mathrm{g}$ for $5 \mathrm{~min}$ and the supernatant recovered. Then, $3 \mathrm{~mL}$ distilled water was added to the pellet and then centrifuged. This process was repeated three times and the supernatant from each process was pooled. The pooled supernatant was centrifuged again $(12,000 \times \mathrm{g}$ for $5 \mathrm{~min}$ ) and the new supernatant was transferred to new tubes. The volume of the final supernatant was exactly diluted to $10 \mathrm{~mL}$ using distilled water and filtered using $0.45 \mathrm{~m}$ nylon filter attached to a syringe. Then, a C18 cartridge was used for SVglys purification. The C18 cartridge was firstly washed with $3 \mathrm{~mL}$ methanol and then conditioned with $3 \mathrm{~mL}$ of distilled water. Thereafter, $0.5 \mathrm{~mL}$ of the filtered supernatant was loaded into the cartridge and then the cartridge was washed with acetonitrile/water mixture (20:80, v/v). Finally, SVglys were eluted from the C18 cartridge with $1 \mathrm{~mL}$ of acetonitrile/water $(80: 20, \mathrm{v} / \mathrm{v})$ and kept in $1.5 \mathrm{~mL}$ tubes at $-20{ }^{\circ} \mathrm{C}$ until further analysis.

For the chromatographic SVglys analysis, two reverse-phase C18 columns were connected in series and a UV-vis detector set at $202 \mathrm{~nm}$ was used. A solvent gradient of acetonitrile and water, as mobile phases, were created with a flow rate of $0.5 \mathrm{~mL} \mathrm{~min}^{-1}$. The acetonitrile ratio was increased into the solvent gradient in 50, 65, 80, 80 and 50\% during 0-10, 10-18, 18-22, 22-24 and 24-30 min, respectively. In order to carry out SVglys assay, $40 \mu \mathrm{L}$ of the purified extract was injected into the HPLC pump. Among SVglys compositions, Reb A, Stev, Reb F, Reb C and Dulc A were detected. For quantification purposes, pure Stev and Reb A (purity >99\%) were used as external standards. Then, Reb F, Reb C, and Dulc A were quantified by their molecular weight ratio to Reb A, because it has been shown that all SVglys have similar molar extinction coefficients (Geuns, 2010). The HPLC peak area was calculated by Chromstar 7.0 software and the results of SVglys content were expressed as a percentage of leaf dry weight $(\mathrm{W} / \mathrm{W})$, using the calibration curves obtained from the relationship between external standards (ppm) and their relative HPLC peak area.

\section{Statistical analysis}

All data was analysis with SAS 9.2 software and means comparisons was performed by Duncan multiple ranges in $5 \%$ of probability. 


\section{Results}

\section{Root characteristics}

The effect of salinity was significant on RFW, RDW, RV, RL, RA, root diameter, RSD, RMD and DRMD (Table 3). With the increasing amount of sodium chloride showed a significant decrease in all root traits measured (Table 4). The highest mean traits of RFW, RDW, RV, RL, RA, root diameter, RSD, RMD, and DRMD were in the $\mathrm{NaCl} 0 \mathrm{mM}$, however, the traits of RDW, RL and DRMD in the $\mathrm{NaCl} 30 \mathrm{mM}$ did not show significant decrease compared to the control (non-stress) (Table 4). The salinity of $\mathrm{NaCl} 60 \mathrm{mM}$ compared to the control $(\mathrm{NaCl} 0 \mathrm{mM})$ causes decreased approximately $50 \%$ in the mean of root characteristics (mentioned above). Salinity level of $\mathrm{NaCl} 150$ $\mathrm{mM}$ compared to the control decreased 80.16, 73.24, 72.10, 73.23 and $72.73 \%$ at RFW, RDW, RV, RL and RA, respectively (Table 3). In Figure 1, the structure of root morphology shown in different levels of sodium chloride.

Table 3. Analysis of variance for effect of salinity $(\mathrm{NaCl})$ on root characteristics of Stevia

\begin{tabular}{|c|c|c|c|c|c|c|c|c|c|c|c|}
\hline \multirow{2}{*}{$\begin{array}{l}\text { Sources of } \\
\text { variance }\end{array}$} & \multicolumn{11}{|c|}{ Mean square (MS) } \\
\hline & df & RFW & RDW & $\mathbf{R V}$ & RL & RA & $\begin{array}{c}\text { Root } \\
\text { diameter }\end{array}$ & RSD & RMD & DRMD & RF \\
\hline $\begin{array}{l}\text { Salinity } \\
(\mathrm{NaCl})\end{array}$ & 5 & $737.2 * *$ & $10.4 * *$ & $703.0^{* *}$ & $8.29 * *$ & $894.1^{* *}$ & $0.21 *$ & $960.1 * *$ & $0.038 * *$ & $0.00055 * *$ & $0.001 \mathrm{~ns}$ \\
\hline $\begin{array}{l}\text { Experimental } \\
\text { error }\end{array}$ & 18 & 20.69 & 0.30 & 20.50 & 0.24 & 12.01 & 0.08 & 18.61 & 0.001 & 0.00001 & 0.001 \\
\hline $\mathrm{CV}(\%)$ & - & 21.15 & 17.26 & 20.12 & 17.26 & 12.34 & 9.33 & 15.64 & 21.15 & 17.26 & 22.16 \\
\hline
\end{tabular}

ns, * and ** non-significant, significant at $5 \%$ and $1 \%$ respectively

(RFW: Root Fresh Weight, RDW: Root Dry Weight, RV: Root Volume, RL: Root Length, RA: Root Area, RSD: Root Surface Area Density, RMD: Root Mass Density, DRMD: Dry Root Mass Density, RF: Root Fineness (Root Length/ Root Fresh Mass)

Table 4. Mean comparison of salinity levels $(\mathrm{NaCl})$ on root parameters of stevia

\begin{tabular}{|c|c|c|c|c|c|c|c|c|c|}
\hline $\begin{array}{c}\text { Salinity } \\
(\mathbf{m M})\end{array}$ & $\begin{array}{c}\mathbf{R F W} \\
(\mathbf{g} / \mathbf{p l a n t})\end{array}$ & $\begin{array}{c}\mathbf{R D W} \\
(\mathbf{g} / \mathbf{p l a n t})\end{array}$ & $\begin{array}{c}\mathbf{R V} \\
\left(\mathbf{c m}^{\mathbf{3}}\right)\end{array}$ & $\begin{array}{c}\mathbf{R L} \\
(\mathbf{m})\end{array}$ & $\mathbf{R A}\left(\mathbf{c m}^{2}\right)$ & $\begin{array}{c}\text { Root } \\
\mathbf{d i a m e t e r} \\
(\mathbf{c m})\end{array}$ & $\begin{array}{c}\mathbf{R S D} \\
\left(\mathbf{( m}^{2} \mathbf{~ m}^{-3}\right)\end{array}$ & $\begin{array}{c}\mathbf{R M D} \\
\left(\mathbf{g ~ m}^{-3}\right)\end{array}$ & $\begin{array}{l}\mathbf{\text { DRMD }} \\
\left(\mathbf{g ~ m}^{-3}\right)\end{array}$ \\
\hline $\mathrm{NaCl}_{0}$ & $44.57 \mathrm{a}$ & $5.42 \mathrm{a}$ & $47.50 \mathrm{a}$ & $4.82 \mathrm{a}$ & $53.47 \mathrm{a}$ & $3.43 \mathrm{a}$ & $51.98 \mathrm{a}$ & $0.323 \mathrm{a}$ & $0.039 \mathrm{a}$ \\
$\mathrm{NaCl}_{30}$ & $28.74 \mathrm{~b}$ & $4.81 \mathrm{a}$ & $26.50 \mathrm{~b}$ & $4.28 \mathrm{a}$ & $37.61 \mathrm{~b}$ & $2.92 \mathrm{~b}$ & $38.87 \mathrm{~b}$ & $0.208 \mathrm{~b}$ & $0.034 \mathrm{a}$ \\
$\mathrm{NaCl}_{60}$ & $20.94 \mathrm{c}$ & $2.98 \mathrm{~b}$ & $19.75 \mathrm{c}$ & $2.65 \mathrm{~b}$ & $25.54 \mathrm{c}$ & $3.17 \mathrm{ab}$ & $26.38 \mathrm{c}$ & $0.151 \mathrm{c}$ & $0.021 \mathrm{~b}$ \\
$\mathrm{NaCl}_{90}$ & $16.83 \mathrm{c}$ & $2.90 \mathrm{~b}$ & $14.25 \mathrm{c}$ & $2.58 \mathrm{~b}$ & $21.29 \mathrm{c}$ & $2.89 \mathrm{~b}$ & $23.27 \mathrm{c}$ & $0.122 \mathrm{c}$ & $0.021 \mathrm{~b}$ \\
$\mathrm{NaCl}_{120}$ & $9.07 \mathrm{~d}$ & $1.66 \mathrm{c}$ & $13.75 \mathrm{c}$ & $1.48 \mathrm{c}$ & $15.95 \mathrm{~d}$ & $2.78 \mathrm{~b}$ & $12.97 \mathrm{~d}$ & $0.065 \mathrm{~d}$ & $0.012 \mathrm{c}$ \\
$\mathrm{NaCl}_{150}$ & $8.84 \mathrm{~d}$ & $1.45 \mathrm{c}$ & $13.25 \mathrm{c}$ & $1.29 \mathrm{c}$ & $14.58 \mathrm{~d}$ & $2.96 \mathrm{~b}$ & $11.96 \mathrm{~d}$ & $0.064 \mathrm{~d}$ & $0.010 \mathrm{c}$ \\
\hline
\end{tabular}

Means in each column followed by similar letter (s), are not significantly different at $5 \%$ probability level, using Duncan's Multiple Range Test

(RFW: Root Fresh Weight, RDW: Root Dry Weight, RV: Root Volume, RL: Root Length, RA: Root Area, RSD: Root Surface Area Density, RMD: Root Mass Density, DRMD: Dry Root Mass Density, RF: Root Length/ Root Fresh Mass) 


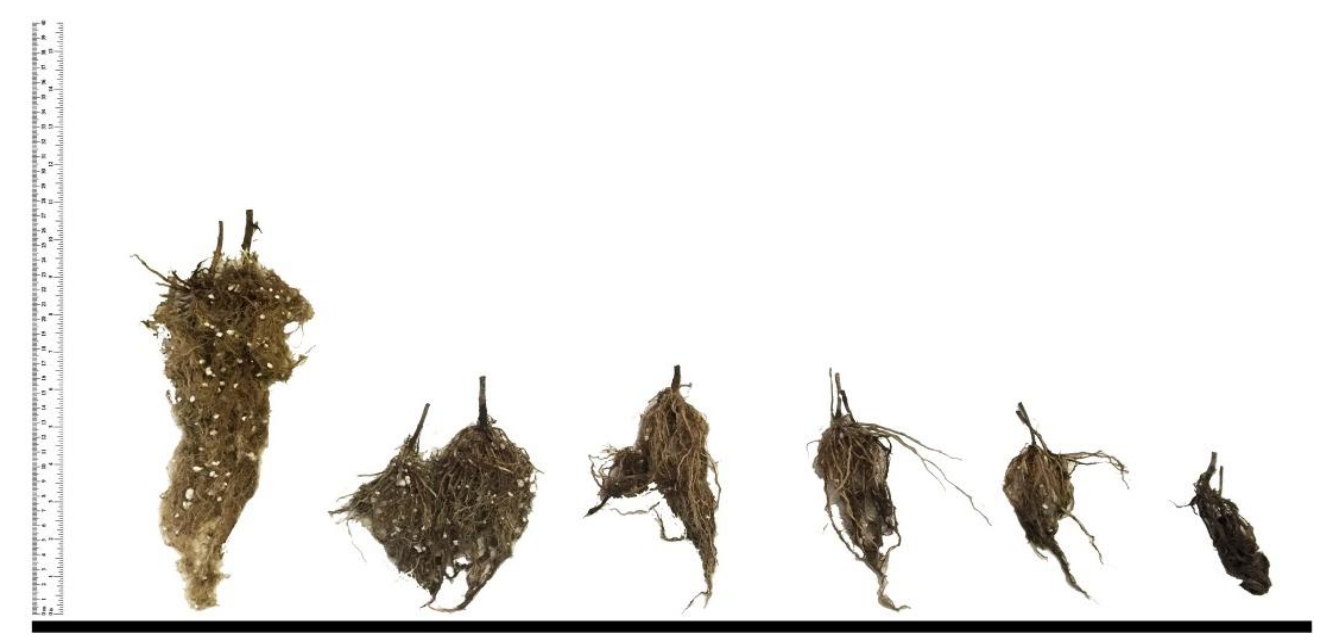

Figure 1. The effect of $\mathrm{NaCl}$ concentration on the root morphology

\section{Physiological traits}

The effect of $\mathrm{NaCl}$ was significant on the protein content, activity of CAT, POD, PPO and DPPH $(\mathrm{P} \leq 0.01)$ (Table 5). The increase of $\mathrm{NaCl}$ concentration caused significantly enhuncment protein content so that the highest protein content was in the highest levels of sodium chloride $(120$ and $150 \mathrm{mM})$ and the lowest protein percentage was control level of salinity (Table 6 ).

Table 5. Analysis of variance for effect of salinity $(\mathrm{NaCl})$ on biochemistry traits of stevia

\begin{tabular}{|c|c|c|c|c|c|c|}
\hline \multirow{2}{*}{ Sources of variance } & \multicolumn{7}{|c|}{ Mean square (MS) } \\
\cline { 2 - 7 } & df & Protein & CAT & POD & PPO & DPPH \\
\hline Salinity $(\mathrm{NaCl})$ & 5 & $31.45^{* *}$ & $38.33^{* *}$ & $2.85^{* *}$ & $29.64 * *$ & $7.94^{* *}$ \\
Experimental error & 18 & 1.05 & 0.17 & 0.01 & 0.79 & 0.064 \\
CV (\%) & - & 10.11 & 11.95 & 9.84 & 25.15 & 10.74 \\
\hline
\end{tabular}

$\mathrm{ns}, *$ and $* *$ non-significant, significant at $5 \%$ and $1 \%$ respectively

Table 6. Mean comparison of salinity levels $(\mathrm{NaCl})$ on biochemistry traits of stevia

\begin{tabular}{|c|c|c|c|c|c|}
\hline Salinity (mM) & Protein $(\%)$ & CAT $(\mathbf{U} / \mathbf{g F W})$ & POD $(\mathbf{U} / \mathbf{g F W})$ & PPO $(\mathbf{U} / \mathbf{g F W})$ & DPPH $(\mathbf{U} / \mathbf{g F W})$ \\
\hline $\mathrm{NaCl}_{0}$ & $5.84 \mathrm{e}$ & $0.021 \mathrm{e}$ & $2.64 \mathrm{a}$ & $8.02 \mathrm{a}$ & $0.61 \mathrm{e}$ \\
$\mathrm{NaCl}_{30}$ & $8.27 \mathrm{~d}$ & $0.123 \mathrm{e}$ & $2.03 \mathrm{~b}$ & $5.24 \mathrm{~b}$ & $1.30 \mathrm{~d}$ \\
$\mathrm{NaCl}_{60}$ & $9.88 \mathrm{c}$ & $2.34 \mathrm{~d}$ & $1.71 \mathrm{c}$ & $3.53 \mathrm{c}$ & $2.03 \mathrm{c}$ \\
$\mathrm{NaCl}_{90}$ & $11.17 \mathrm{bc}$ & $5.18 \mathrm{c}$ & $0.89 \mathrm{~d}$ & $2.36 \mathrm{~cd}$ & $2.36 \mathrm{c}$ \\
$\mathrm{NaCl}_{120}$ & $12.46 \mathrm{ab}$ & $6.26 \mathrm{~b}$ & $0.73 \mathrm{~d}$ & $1.42 \mathrm{de}$ & $3.67 \mathrm{~b}$ \\
$\mathrm{NaCl}_{150}$ & $13.43 \mathrm{a}$ & $7.04 \mathrm{a}$ & $0.50 \mathrm{e}$ & $0.67 \mathrm{e}$ & $4.19 \mathrm{a}$ \\
\hline
\end{tabular}

Means in each column followed by similar letter (s), are not significantly different at $5 \%$ probability level, using Duncan's Multiple Range Test 
The highest and lowest CAT activity were in $\mathrm{NaCl} 150 \mathrm{mM}$ and control levels respectively, in other words, increasing sodium chloride increased CAT activity (Table 6).

The POD activity showed a significant decrease in the increasing amount of sodium chloride so that the highest activity of this enzyme was in control level and lowest activity was at the highest level of salinity $(\mathrm{NaCl} 150 \mathrm{mM})$ (Table 6).

The activity of PPO and POD showed a significant decrease by the increasing amount of sodium chloride (on the contrary CAT activity), so that in the $\mathrm{NaCl} 0 \mathrm{mM}$ and $\mathrm{NaCl} 150 \mathrm{mM}$ observed the highest and lowest activity of this enzymes respectively (Table 6).

The total antioxidant activity DPPH significantly increased by the increasing sodium chloride. In other words, salinity stress was significantly increased the antioxidant capacity of the plant, so that the lowest of activity was in control level and the highest activity was $\mathrm{NaCl} 150 \mathrm{mM}$ (Table 6).

\section{SVglys production}

The salinity caused a significant variation in SVglys compositions and SVglys content of stevia (Table 7). In the $\mathrm{NaCl} 30 \mathrm{mM}$ obtained the highest value of total SVglys yield and SVglys content $(0.51 \mathrm{~g} /$ plant and $12.47 \%$ of the leaf dry weight, respectively) (Table 8). However, regarding SVglys yield of stevia, there was no significant difference between control, $\mathrm{NaCl} 30$, and $\mathrm{NaCl} 60 \mathrm{mM}$ treatment.

The effect of $\mathrm{NaCl}$ treatment was significant on SVglys compositions (Such as Stev, Reb A, Reb B, Reb C and Dulc A). The highest value of Stev, Reb A, Reb B, Reb C and Dulc A were achieved in $\mathrm{NaCl} 30 \mathrm{mM}$ level. The Svglys compositions increased by $\mathrm{NaCl} 30 \mathrm{mM}$ treatment and thereafter decreased when the stress became more severe. Reb A/Stev ratio (sweetness quality) was significantly affected by $\mathrm{NaCl}$ treatment with the highest value in $\mathrm{NaCl} 90$ and $\mathrm{NaCl} 120 \mathrm{mM}$ treatments (Table 8).

\section{Discussion}

Salinity is one of the factors reducing growth and yield of many crops around the world and also, affect on growth and composition of secondary metabolites in medicinal plants (Aghaei Joubani, 2015). The $\mathrm{NaCl}$ stress caused a decrease in all root traits measured (Such as RFW, RDW, RV, RL, RA, root diameter, RSD, RMD, and DRMD). By increasing salinity levels, root morphology were bulky, shorter and slower growth (Figure 1). Reported that salinity stress decrease RL, RF, and RDW in quinoa plant (Panuccio et al., 2014). Root is an organ which could affect resource conversion, use efficiency and transduction of production sources. So structural changes in root morphology caused by salinity stress could alter root structure and affected physiological process occurred in the root (water absorbance and nutrient availability) (Malamy, 2005; Panuccio et al., 2014).

Safwat et al. (2016) reported that salinity decreased root number and length in stevia. The RFW and RDW in Periploca sepium Bunge were reduced strongly with increasing salinity levels (Sun et al., 2011). Researchers mentioned the reduction of photosynthesis, degradation of cell membranes, reduction water availability to roots and accumulation of sodium ions as the main factors reduce plant growth under salt stress (Sharifi et al., 2007). 
Table 7. Analysis of variance for SVglys compositions of stevia under $\mathrm{NaCl}$ treatments $(0$, $30,60,90,120$ and $150 \mathrm{mM}$ )

\begin{tabular}{|c|c|c|c|c|c|c|c|c|c|}
\hline \multirow{2}{*}{$\begin{array}{c}\text { Sources of } \\
\text { variance }\end{array}$} & \multicolumn{9}{|c|}{ Mean square (MS) } \\
\cline { 2 - 10 } & df & Stev & Reb A & Reb B & Reb C & Dulc A & $\begin{array}{c}\text { Total } \\
\text { SVglys }\end{array}$ & $\begin{array}{c}\text { Reb A/Stev } \\
\text { ratio }\end{array}$ & $\begin{array}{c}\text { SVglys } \\
\text { yield }\end{array}$ \\
\hline Salinity $(\mathrm{NaCl})$ & 5 & $18.06 * *$ & $1.33^{* *}$ & $0.041^{*}$ & $0.0061^{* *}$ & $0.036^{* *}$ & $34.25^{* *}$ & $0.0151^{* *}$ & $0.104 * *$ \\
Error & 18 & 0.026 & 0.023 & 0.0004 & 0.00009 & 0.0038 & 0.043 & 0.0018 & 0.009 \\
$\mathrm{CV}(\%)$ & - & 3.16 & 7.53 & 7.92 & 6.20 & 10.23 & 2.53 & 10.58 & 27.14 \\
\hline
\end{tabular}

$\mathrm{ns}, *$ and $* *$ non-significant, significant at $5 \%$ and $1 \%$ respectively

(SVglys: Steviol glycosides; Stev: Stevioside; Reb A: RebaudiosideA; Reb C: Rebaudioside C; Dulc A: Dulcoside A)

Table 8. Mean comparison of salinity levels ( $\mathrm{NaCl}$ ) on SVglys compositions of stevia

\begin{tabular}{|c|c|c|c|c|c|c|c|c|}
\hline $\begin{array}{c}\text { Salinity } \\
(\mathbf{m M})\end{array}$ & Stev (\%) & $\begin{array}{c}\text { Reb A } \\
(\%)\end{array}$ & $\begin{array}{c}\text { Reb B } \\
(\%)\end{array}$ & Reb C (\%) & Dulc A (\%) & $\begin{array}{c}\text { Total Svglys } \\
\text { (percent of leaf } \\
\text { dry matter) }\end{array}$ & $\begin{array}{c}\text { Reb A/Stev } \\
\text { ratio }\end{array}$ & $\begin{array}{c}\text { SVglys yield } \\
\text { (g/plant) }\end{array}$ \\
\hline $\mathrm{NaCl}_{0}$ & $5.74 \mathrm{c}$ & $2.03 \mathrm{c}$ & $0.26 \mathrm{c}$ & $0.16 \mathrm{c}$ & $0.61 \mathrm{bc}$ & $8.83 \mathrm{c}$ & $0.35 \mathrm{c}$ & $0.46 \mathrm{ab}$ \\
$\mathrm{NaCl}_{30}$ & $8.25 \mathrm{a}$ & $2.82 \mathrm{a}$ & $0.43 \mathrm{a}$ & $0.21 \mathrm{a}$ & $0.75 \mathrm{a}$ & $12.48 \mathrm{a}$ & $0.34 \mathrm{c}$ & $0.51 \mathrm{a}$ \\
$\mathrm{NaCl}_{60}$ & $6.83 \mathrm{~b}$ & $2.54 \mathrm{~b}$ & $0.34 \mathrm{~b}$ & $0.18 \mathrm{~b}$ & $0.66 \mathrm{~b}$ & $10.57 \mathrm{~b}$ & $0.37 \mathrm{bc}$ & $0.47 \mathrm{ab}$ \\
$\mathrm{NaCl}_{90}$ & $3.88 \mathrm{~d}$ & $1.84 \mathrm{c}$ & $0.20 \mathrm{~d}$ & $0.13 \mathrm{~d}$ & $0.57 \mathrm{bcd}$ & $6.65 \mathrm{~d}$ & $0.47 \mathrm{a}$ & $0.33 \mathrm{~b}$ \\
$\mathrm{NaCl}_{120}$ & $3.28 \mathrm{e}$ & $1.56 \mathrm{~d}$ & $0.18 \mathrm{~d}$ & $0.12 \mathrm{de}$ & $0.53 \mathrm{~cd}$ & $5.70 \mathrm{e}$ & $0.47 \mathrm{a}$ & $0.16 \mathrm{c}$ \\
$\mathrm{NaCl}_{150}$ & $2.99 \mathrm{f}$ & $1.30 \mathrm{e}$ & $0.17 \mathrm{~d}$ & $0.10 \mathrm{e}$ & $0.48 \mathrm{~d}$ & $5.07 \mathrm{f}$ & $0.43 \mathrm{ab}$ & $0.15 \mathrm{c}$ \\
\hline
\end{tabular}

Means in each column followed by similar letter (s), are not significantly different at $5 \%$ probability level, using Duncan's Multiple Range Test

(SVglys: Steviol glycosides; Stev: Stevioside; Reb A: RebaudiosideA; Reb C: Rebaudioside C; Dulc A: Dulcoside A)

The salinity stress an important subject is the generation of excessive ROS which caused membrane destruction, cell toxicity, and cell death (Chookhampaeng et al., 2008). According to researchers opinion, salinity stress converts superoxide radical $\left(\mathrm{O}_{2}\right)$ to hydrogen peroxide $\left(\mathrm{H}_{2} \mathrm{O}_{2}\right)$ within the cell, this conversion prevents Calvin cycle activity and the process carbohydrates in plants. Therefore increase in activity of antioxidant enzymes such as CAT and SOD was from adverse effects of hydrogen peroxide formed which impact on the carbohydrates production in the chloroplasts. High levels of antioxidant activity in plants under stress are not the only mechanism of salinity tolerance, but also this mechanism can be compatible with components suppliers such as proline and carbohydrates to increase crop tolerance (Abo-Kassem, 2007).

Also, in this experiment, salinity increased CAT activity and total antioxidant activity DPPH in stevia (Table 6). CAT is an important antioxidant enzyme that converts $\mathrm{H}_{2} \mathrm{O}_{2}$ to water in the peroxisomes. In this organelle, $\mathrm{H}_{2} \mathrm{O}_{2}$ is produced from $\beta$-oxidation of fatty acids and photorespiration. Higher activity of CAT and Ascorbate peroxidase decreased $\mathrm{H}_{2} \mathrm{O}_{2}$ rate in cell and increased the stability of membranes and $\mathrm{CO}_{2}$ fixation because several enzymes of the Calvin cycle within chloroplasts are extremely sensitive to $\mathrm{H}_{2} \mathrm{O}_{2}$. A high level of $\mathrm{H}_{2} \mathrm{O}_{2}$ directly inhibits $\mathrm{CO}_{2}$ fixation (Bhutta, 2011). The activity 
of the enzyme of CAT is higher than that of POD, PPO, and DPPH at $\mathrm{NaCl} 150 \mathrm{mM}$, which suggests that $\mathrm{CAT}$ provides a better defense mechanism against $\mathrm{NaCl}$ stressinducted oxidative damage in stevia. The results are similar to Sun et al. (2011); Yeonghoo et al. (2004).

Stevia plants have gained importance as sweeteners because of their Stev and RebA contents. The results indicated that $\mathrm{NaCl} 30 \mathrm{mM}$ (low salinity level) compared to the non-salinity (control) caused increases of SVglys compositions and SVglys yield. Similar results were also obtained by Zheng et al. (2013), who found that lower salinity concentration in soil could alter the composition of SVglys by distinctly improving Reb A content. However, higher $\mathrm{NaCl}$ levels $(90,120$ and $150 \mathrm{mM}$ ) causes prominent decrease of SVglys composition (Such as Stev, Reb A, Reb B, Reb C and Dulc A) and SVglys yield. Zheng et al. (2013) also reported similar results. It seems that when plants lived under high salinity stress conditions, energy was first allocated to the process of maintaining metabolic homeostasis, such as synthesis of simple osmolytes and enhancing activities of antioxidant enzymes (Abrol et al., 2012) rather than the synthesis of complex secondary metabolites. The concentrations of various secondary plant products are strongly dependent on the growing conditions and have an impact on the metabolic pathways responsible for the accumulation of the related natural products (Ramakrishna and Ravishamkar, 2011).

\section{Conclusion}

The $\mathrm{NaCl}$ stress caused changes in physiological traits and reduces of root characteristics (caused decrease approximately 50\% in the mean traits of root characteristics). The increaseing antioxidant defense system (DPPH, CAT, POD and PPO) also responded to this stress. The level of $\mathrm{NaCl} 30 \mathrm{mM}$ (low salinity) compared to the non-salinity caused increase of SVglys compositions and SVglys yield. It seems that increasing the SVglys rate in low levels of salinity stress can be one of the tolerance mechanisms in the plant, which requires further research.

Acknowledgements. The authors are thankful to colleagues in the Central Laboratory and Medicinal Plant Research Center of the Shahed University, for help to field management and chemical analysis.

\section{REFERENCES}

[1] Abo-Kassem, E. E. (2007): Effects of salinity: Calcium interaction on growth and nucleic acid metabolism in five species of Chenopodiaceae. - Turkish Journal of Botany 31(2): $125-134$.

[2] Abrol, E., Vyas, D., Koul, S. (2012): Metabolic shift from secondary metabolite production to induction of antioxidative enzymes during $\mathrm{NaCl}$ stress in Swertia chirata Buch. - Ham Acta Physiol Plant 34: 541-546.

[3] Aghaei, K., Ehsanpour, A., Shah, A., Komatsu, S. (2009): Proteome analysis of soybean hypocotyl and root under salt stress. - Amino Acids 36(1): 91-98.

[4] Aghaei-Joubani, K. A. T., Najmeh, A. K., Mohammad, R. A., Yazdani, M. (2015): Effect of salt stress on some physiological and biochemical parameters of two Salvia species. Journal of Plant Process and Function 3(9): 85-96. 
[5] Azizpour, K., Shakiba, M., Sima, N. K. K., Alyari, H., Mogaddam, M., Esfandiari, E., Pessarakli, M. (2010): Physiological response of spring durum wheat genotypes to salinity. - Journal of Plant Nutrition 33(6): 859-873.

[6] Barbet-Massin, C., Giuliano, S., Alletto, L., Daydé, J., Berger, M. (2016): Towards a semi-perennial culture of Stevia rebaudiana (Bertoni) under temperate climate: effects of genotype, environment and plant age on steviol glycoside content and composition. Genetic Resources and Crop Evolution 63(4): 685-694.

[7] Bazrafshan, A., Ehsanzadeh, P. (2016): Evidence for differential lipid peroxidation and antioxidant enzyme activities in Sesamum indicum L. genotypes under $\mathrm{NaCl}$ salinity. Journal of Agricultural Science and Technology 18(1): 202-222.

[8] Bhutta, W. (2011): Antioxidant activity of enzymatic system of two different wheat (Triticum aestivum L.) cultivars growing under salt stress. - Plant Cell Environ 57: 101107.

[9] Bradford, M. M. (1976): A rapid and sensitive method for quantitation of microgram quantities of protein utilizing the principle of protein-dye binding. - Annual Review of Biochemistry 72: 248-254.

[10] Brand-Williams, W., Cuvelier, M. E., Berset, C. (1995): Use of free radical method to evaluate antioxidant activity. - Lebensm Wiss Technology 28: 25-30.

[11] Ceunen, S., Geuns, J. (2013): Influence of photoperiodism on the spatiotemporal accumulation of steviol glycosides in Stevia rebaudiana (Bertoni). - Plant Science 198: $72-82$.

[12] Chance, B., Maehly, A. C. (1995): Assay of Catalase and Peroxidase. - Academic Press, New York.

[13] Chookhampaeng, S., Pattanagul, W., Theerakulpisut, P. (2008): Effects of salinity on growth, activity of antioxidant enzymes and sucrose content in tomato (Lycopersicon esculentum Mill.) at the reproductive stage. - Science Asia 34: 69-75.

[14] De Oliveira, A. C., Varshney, R. K. (2011): Root Genomics, pp. 1-10. - Springer, Berlin.

[15] Ganjali, A., Kafi, M., Bagheri, A., Shahriari, F. (2003): Allometric relationship between root and shoot characteristics of chickpea seedlings (Cicer arietinum). - Journal of Agriculture Science and Technology 18: 67-80.

[16] Geuns, J. M. C. (ed.) (2010): Stevia and Steviol Glycosides. - Euprint, Heverlee.

[17] Gharsallah, C., Fakhfakh, H., Grubb, D., Gorsane, F. (2016): Effect of salt stress on ion concentration, proline content, antioxidant enzyme activities and gene expression in tomato cultivars. - AoB Plants 8: 1-22.

[18] Gupta, P., Sharma, S., Saxena, S. (2016): Effect of abiotic stress on growth parameters and steviol glycoside content in Stevia rebaudiana (Bertoni) raised in vitro. - Journal of Applied Research on Medicinal and Aromatic Plants 3(4): 160-167.

[19] Hajabbasi, M. A. (2001): Tillage effects on soil compactness and wheat root morphology. - Journal of Agriculture Science and Technology 3: 67-77.

[20] Hajar, E. W. I., Sulaiman, A. Z. B., Sakinah, A. M. M. (2014): Assessment of heavy metals tolerance in leaves, stems and flowers of Stevia rebaudiana plant. - Procedia Environment Science 20: 386-393.

[21] Hajihashemi, S., Ehsanpour, A. A. (2014): Antioxidant response of Stevia rebaudiana B. to polyethylene glycol and paclobutrazol treatments under in vitro culture. - Applied Biochemistry and Biotechnology 172(8): 4038-4052.

[22] Ityel, E., Lazarovitch, N., Silberbush, M., Ben-Gal, A. (2012): An artificial barrier to improving root-zone conditions for horticultural crops: response of pepper plants to matric head and irrigation water salinity. - Agriculture Water Management 105: 13-20.

[23] Jamil, M., Bashir, S., Anwar, S., Bibi, S., Bangash, A., Ullah, F., Shikrha, E. (2012): Effect of salinity on physiological and biochemical characteristics of different varieties of rice. - Pakistan Journal of Botany 44: 7-13.

[24] Karimi, M., Ahmadi, A., Hashemi, J., Abbasi, A., Tavarini, S., Guglielminetti, L., Angelini, L. G. (2015): The effect of soil moisture depletion on stevia (Stevia rebaudiana 
Bertoni) grown in greenhouse conditions: Growth, steviol glycosides content, soluble sugars and total antioxidant capacity. - Scientia Horticulturae 183: 93-99.

[25] Liu, H., Tang, C., Li, C. (2016): The effects of nitrogen form on root morphological and physiological adaptations of maize, white lupin and faba bean under phosphorus deficiency. - AoB Plants 8: 1-14.

[26] Malamy, J. (2005): Intrinsic and environmental response pathways that regulate root system architecture. - Plant, Cell \& Environment 28(1): 67-77.

[27] Montaña, L. A., Fischer, G., Magnitskiy, S., Zuluaga, G. (2014): Effect of NaCl salinity on seed germination and seedling emergence of purple passion fruit (Passiflora edulis Sims). - Agronomía Colombiana 32(2): 188-195.

[28] Munns, R., Tester, M. (2008): Mechanisms of salinity tolerance. - Annual Review Plant Biology 59: 651-681.

[29] Ober, E. S., Sharp, R. E. (2007): Regulation of root growth responses to water deficit advances in molecular breeding toward drought and salt tolerant crops, pp. 33-53. Springer, Dordrecht.

[30] Panuccio, M., Jacobsen, S. E., Akhtar, S. S., Muscolo, A. (2014): Effect of saline water on seed germination and early seedling growth of the halophyte quinoa. - AoB Plants 6: $1-18$.

[31] Polle, A., Otter, T., Seifert, F. (1994): Apoplastic peroxidase and lignifications in needles of Norway Spruce Picea abies L. - Plant Physiology 106: 53-60.

[32] Rahimi, A., Biglarifard, A. (2011): Influence of $\mathrm{NaCl}$ salinity and different substracts on plant growth, mineral nutrient assimilation and fruit yield of strawberry. - Notulae Botanicae Horti Agrobotanici Cluj-Napoca 39(2): 219.

[33] Ramakrishna, A., Ravishankar, G. A. (2011): Influence of abiotic stress signals on secondary metabolites in plants. - Plant Signaling and Behavior 6(11): 1720-1731.

[34] Raymond, J., Rakariyatham, N., Azanza, J. L. (1993): Purification and some properties of polyphenol oxidase from sunflower seeds. - Phytochemistry 34: 927-931.

[35] Reis, M., Coelho, L., Santos, G., Kienle, U., Beltro, J. (2015): Yield response of stevia (Stevia rebaudiana Bertoni) to the salinity of irrigation water. - Agriculture Water Management 152: 217-221.

[36] Safwat, A. A., Amany, K. I., Marwa, S. G., Walid, W. M., Salah, K. (2016): Diatomite alleviates the adverse effects of salinity stress on growth and yield of Stevia rebaudiana. - International Journal of Advanced Biotechnology and Research 7(1): 10-21.

[37] Sharifi, M., Ghorbanli, M., Ebrahimzadeh, H. (2007): Improved growth of salinitystressed soybean after inoculation with salt pre-treated mycorrhizal fungi. - Journal of Plant Physiology 164(9): 1144-1151.

[38] Singh, D., Massod Ali, R., Basu, P. (2000): Genetic variation in dry matter partitioning in shoot and root influnces of chickpea to drought. - Paper presented at the 3rd International Crop Science Congress, Hamburg.

[39] Sun, J. K., Li, T., Xia, J. B., Tian, J. Y., Lu, Z. H. (2011): Influence of salt stress on ecophysiological parameters of Periploca sepium Bunge. - Plant Soil Environment 57: 139-144.

[40] Wu, Q., Zou, Y., Liu, W., Ye, X., Zai, H., Zhao, L. (2010): Alleviation of salt stress in citrus seedlings inoculated with mycorrhiza: changes in leaf antioxidant defense systems. - Plant Soil Environment 56(10): 470-475.

[41] Yeonghoo, K., Joji, A., Takuji, N., Norikazu Shinji, S., Kenji, U. (2004): Antioxidative responses and their relation to salt tolerance in Echinochloa oryzicolaVasing and Setaria virdis (L.) Beauv. - Plant Growth Regulation 44: 87-92.

[42] Zheng, J., Chen, C., Li, D., Yi, B., Wy, W. (2013): Effects of salt stress on the growth, physiological responses, and Glycoside contents of Stevia rebaudiana Bertoni. - Journal of Agricultural and Food Chemistry 61: 5720-5726. 